\title{
EVALUASI PEMOTONGAN, PENYETORAN, DAN PELAPORAN PPH PASAL 23 PADA JASA PENGIRIMAN BARANG (PENGEPAKAN) DAN CLEANING SERVICE PADA PT KIMIA FARMA TRADING \& DISTRIBUTION MAKASSAR
}

\author{
Andi Saprianti $^{(1)}$, Lina Mariana ${ }^{(2)}$ \\ (Politeknik Informatika Nasional) \\ linamariana5390@gmail.com
}

\begin{abstract}
ABSTRAK
PT Kimia Farma Trading \& Distribution melakukan transaksi terkait layanan dalam aktivitasnya. PT Kimia Farma Trading \& Distribution bekerja dengan lima mitra penyedia layanan. Salah satu mitranya adalah PT Lestari Jaya Raya Sentosa, yang bergerak di bidang jasa pengiriman (packing). PT Glori Sukses Makmur juga bekerja sama dengan PT Kimia Farma Trading \& Distribution dalam menyediakan layanan pembersihan. Tujuan dari penelitian ini adalah untuk mengetahui Pasal 23 Pemotongan, Penyetoran dan Pelaporan Pajak Penghasilan atas Jasa Pengiriman dan Pengepakan Barang di PT Kimia Farma Trading \& Distribution. Metode analisis penelitian yang digunakan adalah kualitatif deskriptif dimana peneliti menggambarkan hasil pengamatan dan analisis data yang diperoleh di lapangan. Penelitian dilakukan dari 12 Agustus 2019 hingga 12 November 2019. Metode pengumpulan data yang digunakan adalah dokumentasi, observasi dan wawancara. Setelah menganalisis dan mendiskusikan masalah tersebut, peneliti menyimpulkan bahwa pemotongan, penyetoran, dan pelaporan pajak penghasilan Pasal 23 sesuai dengan ketentuan umum. Ketentuan Perpajakan.
\end{abstract}

Keywords: Evaluasi, Pemotongan, Setoran, Pelaporan PPH Pasal 23

\section{PENDAHULUAN}

Negara Indonesia merupakan Negara berkembang, yang terdiri dari ribu an pulau yang memiliki budaya yang beraneka ragam, lautan, dan sumberdaya alam yang melimpah. Dengan perkembangan yang terjadi saat ini mendorong pemerintah untuk melakukan perubahan di segala sektor demi meningkatkan pendapatan atau kas negara guna membiayai pembangunan. Dalam melakukan perubahan tersebut, pastilah memerlukan dana yang sangat besar.

Dana yang digunakan untuk pembangunan Negara berasal dari 
Anggaran Pendapatan Belanja Negara (APBN) dan Anggaran Pendapatan Daerah (APBD), dimana sebagian besar bersumber dari penerimaan pajak. Pajak memiliki peranan yang sangat penting dalam kehidupan bernegara, kh ususnya didalam pelaksanaan pembangunan karena pajak sendiri merupakan sumber pendapatan Negara untuk membiayai semua pengeluaran termasuk pengeluaran pembangunan nasional. Sebagai salah satu sumber penerimaan Negara paling besar, maka penting untuk meningkatkan kesejahteraan dan kemakmuran seluruh rakyat Indonesia adalah dengan adanya partisipasi rakyat Indonesia dalam membayar pajak.

Untuk itu pajak sebagai sumber pendapatan dan penerimaan negara perlu terus di tingkatkan, sehingga pembangunan nasional dapat di laksanakan dengan kemampuan sendiri berdasarkan prinsip kemandirian. Kesadaran setiap Wajib Pajak (WP) di bidang perpajakan harus di tingkatkan, karena pada kenyataannya masih banyak Wajib Pajak yang belum tahu akan hak dan kewajibannya di bidang perpajakan. Salah satu caranya adalah dengan partisipasi seluruh masyarakat serta para tempat penyelenggara pemerintah sebagai abdi bangsa sangat perlu untuk melancarkan administrasi perpajakan dalam rangka meningkatkan pendapatan negara. Besar atau kecilnya pajak yang diterima oleh negara sangat berpengaruh terhadap jalannya pembangunan. Semakin besar jumlah angka pajak yang diterima oleh negara, maka kesempatan untuk membangun ataupun membenahi pembangunan di setiap sektornya, akan semakin cepat terealisasi, sehingga merata dan dampaknya bisa dirasakan oleh seluruh kalangan masyarakat.

Sebaliknya apabila penerimaan pajak yang diterima negara kecil, maka otomatis akan memperlambat perkembangan pembangunan yang sedang berjalan. Akan tetapi sangat disayangkan, karena masih banyak masyarakat yang belum menyadari pentingnya membayar pajak.

Untuk itulah pemerintah mempunyai tugas yang cukup berat untuk menyadarkan setiap warganya untuk mematuhi peraturan mengeanai pajak. Salah satu jenis pajak yang kita kenal yaitu Pajak Penghasilan (PPh) Pasal 23. Ada dua dasar pemotongan pajak penghasilan pasal 23 yaitu dari jumlah 
bruto untuk penghasilan berupa deviden, bunga termasuk premium, diskonto, imbalan sehubungan dengan jaminan pengembalian hutang, royalti, hadiah dan dari perkiraan penghasilan neto untuk penghasilan berupa sewa dan penghasilan lain sehubungan dengan penggunaan harta, imbalan sehubungan dengan jasa teknik, jasa manajemen, jasa konstruksi, jasa konsultan, dan jasa selain yang telah di potong PPh pasal 21.

PT Kimia Farma Trading \& Distribution dalam kegiatannya juga melakukan transakasi yang berhubungan dengan jasa. PT Kimia Farma Trading \& Distribution bekerja sama dengan lima mitra penyedia jasa. Salah satu mitranya adalah PT Lestari Jaya Raya Sentosa yang bergerak dalam bidang jasa pengiriman barang (pengepakan). PT Glori Sukses Makmur juga bekerja sama dengan PT Kimia Farma Trading \& Distrubution dalam menyediakan jasa kebersihan atau cleaning service. Berdasarkan jenis kegiatan tersebut, maka PT Kimia Farma selaku pengguna jasa kedua perusahaan tersebut melakukan pemotongan pph pasal 23.

\section{TELAAH LITERATUR DAN PENGEMBANGAN HIPOTESIS}

\section{Pengertian Pajak}

Menurut UU No.28 Tahun 2007 Pasal 1 Tentang Ketentuan Umum dan Perpajakan :

Pajak merupakan suatu konstribusi wajib kepada negara yang terhutang oleh setiap orang maupun badan yang sifatnya memaksa namun tetap berdasarkan pada Undang-Undang, dan tidak mendapat imbalan secara langsung serta digunakan untuk kebutuhan negara juga kemakmuran rakyatnya.

Pengertian Pajak Menurut Para Ahli dalam buku (Rahayu, Perpajakan Konsep dan Aspek Formal, 2017), antara lain sebagai berikut:

a) Prof. Dr. MJH. Smeeths

Pajak adalah sebuah prestasi pemerintah yang terhutang melalui norma-norma dan dapat dipaksakan tanpa adanya suatu kontra prestasi dari setiap individual. Maksudnya ialah membiayai pengeluaran pemerintah atau negaranya.

b) Prof. Dr. Rochmat Soemitro, SH. 
Menurutnya, pajak ialah iuran rakyat kepada negaranya berdasarkan Undang-Undang atau peralihan kekayaan dari sektor swasta kepada sektor publik yang bisa dipaksakan dan yang langsung dapat ditunjuk serta digunakan untuk membiayai kebutuhan atau kepentingan umum.

Pajak menurut Prof. Dr. PJA Andriani yang dikutip oleh (Mariana, 2018) mengemukakan bahwa pajak merupakan iuran rakyat atau masyarakat pada negara yang bisa dipaksakan dan terhutang bagi yang wajib membayarnya sesuai dengan peraturan UU dengan tidak memperoleh suatu imbalan yang langsung bisa ditunjuk serta.

\section{Pajak Penghasilan (PPh) 23}

Ketentuan dalam Pasal 23 UU No. 28 Tahun 2007, merupakan pemotongan pajak atas penghasilan yang diterima atas diperoleh Wajib Pajak dalam negeri dan Bentuk Usaha Tetap yang berasal dari modal, penyerahan jasa, atau menyelenggara kegiatan selain yang telah dipotong Pajak Penghasilan Pasal 21 yang dibayarkan, disediakan untuk dibayarkan, atau telah jatuh tempo pembayarannya oleh badan pemerintah, subjek pajak badan dalam negeri, penyelenggara kegiatan, bentuk usaha tetap, atau perwakilan perusahaan luar negeri lainnya.

a) Ruang Lingkup Pemotongan PPh Pasal 23 Pada dasarnya pengenaan Pajak Penghasilan Pasal 23 baru bisa dilakukan jika telah memenuhi ruang lingkup pengenaan, yaitu pemberi penghasilan memenuhi kriteria sebagai pemotong PPh Pasal 23, penerima penghasilan memenuhi kriteria sebagai pihak yang dipotong PPh Pasal 23 dan jenis penghasilan yang dibayarkan adalah termasuk penghasilan-penghasilan yang merupakan objek pemotongan PPh Pasal 23.

b) Pengertian PPh Pasal 23

Pajak yang dipotong atas penghasilan yang berasal dari deviden, bunga, royalty, sewa, dan penghasilan lain atas penggunaan harta dan imbalan jasa teknik / manajemen dan jasa lainnya.

c) Pemotong Pajak Penghasilan Pasal 23

Berdasarkan ketentuan Pasal 23 ayat (1) Undang-undang Nomor 7 Tahun 1983 sebagaimana telah diubah terakhir dengan Undangundang Nomor 36 Tahun 2008 (Undang-undang Pajak Penghasilan 1984), pemotong Pajak Penghasilan (PPh) Pasal 23 adalah :

1) Badan Pemerintah 
Tidak ada penjelasan dalam Undang-undang Pajak Penghasilan tentang arti Badan Pemerintah ini. Namun demikian, tidak sulit untuk mengartikan bahwa yang dimaksud dengan Badan Pemerintah adalah Pemerintah negara Republik Indonesia dan Pemerintah Daerah di Indonesia beserta instansi-instansi di bawahnya. Dalam prakteknya, pemotongan PPh Pasal 23 oleh instansi pemerintah dilakukan oleh bendahara pemerintah.

2) Subjek Pajak Badan dalam negeri

Berdasarkan Pasal 2 ayat (3) huruf b Undang-undang Pajak Penghasilan 1984, subjek pajak badan dalam negeri adalah badan yang didirikan atau bertempat kedudukan di Indonesia. Istlah didirikan mengandung arti bahwa badan tersebut didirikan berdasarkan ketentuan hukum di Indonesia. Sementara itu istilah bertempat kedudukan menunjukkan bahwa badan tersebut memiliki efektif manajemen di Indonesia di mana pengambilan keputusan-keputusan penting tentang badan tersebut dilakukan di Indonesia.

Pengertian badan sendiri berdasarkan Pasal 2 ayat (1) huruf $b$ Undang-undang Pajak Penghasilan 1984 adalah sekumpulan orang dan/atau modal yang merupakan kesatuan baik yang melakukan usaha maupun yang tidak melakukan usaha yang meliputi perseroan terbatas, perseroan komanditer, perseroan lainnya, badan usaha milik negara atau badan usaha milik daerah dengan nama dan dalam bentuk apa pun, firma, kongsi, koperasi, dana pensiun, persekutuan, perkumpulan, yayasan, organisasi massa, organisasi sosial politik, atau organisasi lainnya, lembaga, dan bentuk badan lainnya termasuk kontrak investasi kolektif dan bentuk usaha tetap

3) Penyelenggara kegiatan

Penyelenggara kegiatan bisa berbentuk badan, orang pribadi atau kepanitiaan yang melakukan suatu event atau kegiatan. Contoh 
penyelenggara kegiatan adalah orang pribadi atau badan yang mengorganisir suatu acara seperti pertunjukkan, perlombaan, seminar dan lain-lain.

4) Bentuk Usaha Tetap (BUT)

BUT adalah bagian dari Subjek Pajak luar negeri yang melakukan kegiatan di Indonesia sehingga menerima atau memperoleh penghasilan yang bersumber dari Indonesia. Walaupun termasuk Wajib Pajak luar negeri, pemenuhan hak dan kewajiban BUT disamakan dengan pemenuhan hak dan kewajiban Wajib Pajak dalam negeri.

Pengertian BUT bisa kita temukan dalam Pasal 2 ayat (5) Undang-undang Pajak Penghasilan, yaitu bentuk usaha yang dipergunakan oleh orang pribadi yang tidak bertempat tinggal di Indonesia, orang pribadi yang berada di Indonesia tidak lebih dari 183 (seratus delapan puluh tiga) hari dalam jangka waktu 12 (dua belas) bulan, dan badan yang tidak didirikan dan tidak bertempat kedudukan di Indonesia untuk menjalankan usaha atau melakukan kegiatan di Indonesia, yang dapat berupa tempat kedudukan manajemen, cabang perusahaan, kantor perwakilan, gedung kantor, pabrik, bengkel dan lain-lain.

5) Perwakilan Perusahaan Luar Negeri Lainnya

Perwakilan perusahaan luar negeri lainnya selain BUT yang ada di Indonesia juga merupakan pemotong PPh Pasal 23. Contohnya adalah Representative Office (RO) dari perusahaan-perusahaan asing.

Ketentuan lebih lanjut tentang hal ini diatur dalam Peraturan Menteri Keuangan Nomor 251/PMK.03/2008 tentang Penghasilan Atas Jasa Keuangan yang dilakukan oleh badan usaha yang berfungsi sebagai penyalur pinjaman dan/atau pembiayaan yang tidak dilakukan pemotongan pajak penghasilan Pasal 23.

Berdasarkan ketentuan ini, penghasilan sehubungan dengan jasa 
keuangan yang tidak dilakukan pemotongan PPh Pasal 23 adalah berupa bunga atau imbalan lain yang diberikan atas penyaluran pinjaman dan atau pemberian pembiayaan, termasuk yang menggunakan pembiayaan berbasis syariah.

Badan usaha jasa keuangan yang atas penghasilannya tidak dipotong PPh Pasal 23 ini terdiri dari :

perusahaan pembiayaan yang merupakan badan usaha di luar bank dan lembaga keuangan bukan bank yang khusus didirikan untuk melakukan kegiatan yang termasuk dalam bidang usaha lembaga pembiayaan dan telah memperoleh ijin usaha dari Menteri Keuangan;

badan usaha milik negara atau badan usaha milik daerah yang khusus didirikan untuk memberikan sarana pembiayaan bagi usaha mikro, kecil, menengah, dan koperasi, termasuk PT (Persero) Permodalan Nasional Madani.

\section{Tarif PPh Pasal 23}

Apabila PPh Pasal 23 bisa dikenakan setelah memenuhi ruang lingkup sebagaimana sudah di jelaskan dalam tulisan Ruang Lingkup Pemotongan PPh Pasal 23, maka pertanyaan berikutnya adalah berapa besar PPh Pasal 23 yang harus dipotong? Untuk menjawab pertanyaan ini, ada dua hal yang harus diperhatikan yaitu tarif pemotongan PPh Pasal 23 dan dasar pengenaan PPh Pasal 23. Tarif PPh Pasal 23 sendiri mengenal dua jenis tarif yaitu tarif $15 \%$ dari jumlah bruto dan tarif $2 \%$ dari jumlah bruto.

\section{a) PPh Pasal 23 Dengan Tarif 15\%}

Berdasarkan Pasal 23 ayat (1) huruf a Undang-undang Pajak

Penghasilan 1984, atas beberapa jenis objek PPh Pasal 23

dikenakan pemotongan PPh Pasal 23 dengan tarif 15\% dari jumlah

bruto. Objek pemotongan PPh Pasal 23 yang dikenakan tarif 15\% dari jumlah bruto ini adalah :

1) Dividen 
2) Bunga.

3) Royalti

4) Hadiah, penghargaan, bonus dan sejenisnya selain yang telah dipotong Pajak Penghasilan (PPh) Pasal 21.

\section{b) PPh Pasal 23 Dengan Tarif 2\%}

Berikut adalah jenis-jenis penghasilan objek pemotongan PPh Pasal 23 yang dikenakan tarif PPh Pasal 23 sebesar $2 \%$ dari jumlah bruto.

1) Sewa dan penghasilan lain sehubungan dengan penggunaan harta,kecuali yang dikenai PPh pasal 4 ayat 2.

2) Imbalan sehubungan dengan jasa teknik, jasa manajemen, jasa konstruksi, jasa konsultan, dan jasa lain.

\section{Tatacara Penyetoran PPh Pasal 23}

Berdasarkan ketentuan Pasal 2 Peraturan Menteri Keuangan Nomor 80/PMK.03/2010 tanggal 1 April 2010 yang merupakan perubahan atas Peraturan Menteri Keuangan Nomor 184/PMK.03/2007, PPh Pasal 23 yang dipotong oleh Pemotong PPh harus disetor paling lama tanggal 10 (sepuluh) bulan berikutnya setelah Masa Pajak berakhir.

Dalam hal tanggal jatuh tempo pembayaran atau penyetoran pajak bertepatan dengan hari libur termasuk hari Sabtu atau hari libur nasional, pembayaran atau penyetoran pajak dapat dilakukan pada hari kerja berikutnya. Dalam pengertian hari libur nasional termasuk hari yang diliburkan untuk penyelenggaraan Pemilihan Umum yang ditetapkan oleh Pemerintah dan cuti bersama secara nasional yang ditetapkan oleh Pemerintah.

Pembayaran dan penyetoran pajak harus dilakukan dengan menggunakan Surat Setoran Pajak (SSP) atau sarana administrasi lain yang disamakan dengan Surat Setoran Pajak. SSP ini berfungsi sebagai bukti pembayaran pajak apabila telah disahkan oleh pejabat kantor penerima pembayaran yang berwenang atau apabila telah mendapatkan validasi. SSP dianggap sah jika telah divalidasi dengan Nomor Transaksi Penerimaan Negara (NTPN). Adapun tempat pembayaran adalah Kantor Pos atau bank 
yang ditunjuk oleh Menteri Keuangan sebagai tempat pembayaran pajak.

\section{Tatacara Pelaporan PPh Pasal 23}

Pemotong PPh Pasal 23 wajib memberikan tanda bukti pemotongan PPh Pasal 23 kepada orang pribadi atau badan yang dipotong setiap melakukan pemotongan atau pemungutan. Bagi penerima penghasilan, bukti pemotongan PPh Pasal 23 ini adalah bukti pelunasan PPh terutang dalam tahun tersebut yang nantinya akan dikreditkan dalam SPT Tahunannya.

Apabila masa pajak telah berakhir, pemotong PPh Pasal 23 wajib melaporkan pemotongan yang telah dilakukan dalam masa pajak tersebut. Pelaporan ini dilakukan dengan menyampaikan SPT Masa PPh Pasal 23/26 ke Kantor Pelayanan Pajak tempat Wajib Pajak pemotong PPh Pasal 23 terdaftar.

Surat Pemberitahuan (SPT) Masa PPh Pasal 23/26 harus disampaikan paling lama 20 (dua puluh) hari setelah Masa Pajak berakhir. Contoh, untuk pemotongan PPh Pasal 23 bulan Oktober 2010, SPT Masa PPh Pasal 23 harus disampaikan paling lambat tanggal 20 Nopember 2010.

Dalam hal batas akhir pelaporan di atas bertepatan dengan hari libur termasuk hari Sabtu atau hari libur nasional, pelaporan dapat dilakukan pada hari kerja berikutnya. Pengertian hari libur nasional termasuk hari yang diliburkan untuk penyelenggaraan Pemilihan Umum yang ditetapkan oleh Pemerintah dan cuti bersama secara nasional yang ditetapkan oleh Pemerintah.

\section{III.METODE PENELITIAN}

\section{Lokasi dan Waktu Penelitian}

Lokasi penelitian pada PT Kimia Farma Trading dan Distribution. JL Kima XV, Daya, Kawasan Industri Kav. R No. 4A, Bira, Makassar, Kota Makassar, Sulawesi Selatan. Sedangkan waktu penelitian dilaksanakan sejak tanggal 12 Agustus 2019 sampai tanggal 12 November 2019. 


\section{Desain Penelitian}

Penelitian ini menggunakan ini pendekatan kualitatif. Menurut Bogdan dan Taylor (1992) Dikutip Dalam Tugas Akhir Muh. Sofyan (2019). menjelaskan bahwa penelitian kualitatif adalah suatu prosedur penelitian yang menghasilkan data deskriptif berupa ucapan atau tulisan dan perilaku orang-orang yang diamati. Pendekatan kualitatif diharapkan mampu menghasilkan uraian yang mendalam tentang ucapan, tulisan dan atau perilaku yang dapat diamati dari suatu individu, kelompok, masyarakat, dan atau organisasi tertentu dalam suatu keadaan konteks tertentu yang dikaji dari sudut pandang yang utuh.

\section{Metode Analisis Data}

Teknik analisis data yang digunakan dalam penelitian ini adalah analisis deskriptif kualitatif, yaitu data dikumpulkan, disusun, dikelompokkan, dan dianalisa. Deskriptif kualitatif juga merupakan analisis yang dilakukan dengan cara mengambarkan fakta atau keadaan yang terjadi di lapangan atas suatu obyek dalam bentuk uraian kalimat berdasarkan informasi dari pihak berwewenang melalui wawancara, pengamatan langsung di lapangan serta laporan yang berhubungan dengan penelitian. (Mariana, 2018)

\section{HASIL PENELITIAN DAN PEMBAHASAN}

\section{Penyajian Data Hasil Penelitian}

Berikut data yang diperoleh dari tempat penelitian:

Tabel 1. Data transaksi Bulan September 2019

\begin{tabular}{|l|l|c|c|}
\hline Nama User & Jenis Transaksi & Jumlah Transaksi & $\begin{array}{c}\text { Jumlah } \\
\text { PPh 23 }\end{array}$ \\
\hline PT. Lestari Jaya Raya Sentosa & Jasa Pengepakan & 11.581 .873 & 231.637 \\
\hline PT. Indah Logistik & Jasa Pengepakan & 54.080 .715 & 1.081 .614 \\
\hline PT Nusa Jaya Ekspress & Jasa Pengepakan & 22.095 .653 & 441.913 \\
\hline Hasrianti & Jasa Pengepakan & 34.495 .000 & 689.900 \\
\hline
\end{tabular}




\begin{tabular}{|l|l|c|c|}
\hline PT Glori Sukses Mandiri & $\begin{array}{l}\text { Jasa Kebersihan atau } \\
\text { Cleaning Service }\end{array}$ & 28.991 .000 & 579.820 \\
\hline
\end{tabular}

Sumber: PT Kimia Farma,2020

Tabel 2. Data Bukti Potong PPh 23 Bulan September 2019

\begin{tabular}{|l|l|l|c|}
\hline Nama User & $\begin{array}{l}\text { Tanggal Bukti } \\
\text { Potong }\end{array}$ & No. Bukti Potong & $\begin{array}{l}\text { Jumlah } \\
\text { PPh 23 }\end{array}$ \\
\hline $\begin{array}{l}\text { PT. Lestari Jaya Raya } \\
\text { Sentosa }\end{array}$ & 27 September 2019 & $000113 /$ PPH23 & 231.637 \\
\hline PT. Indah Logistik & 27 September 2019 & $000114 /$ PPH23 & 1.081 .614 \\
\hline PT Nusa Jaya Ekspress & 27 September 2019 & $000115 /$ PPH23 & 441.913 \\
\hline Hasrianti & 27 September 2019 & $000116 /$ PPH23 & 689.900 \\
\hline PT Glori Sukses Mandiri & 27 September 2019 & $000117 /$ PPH23 & 579.820 \\
\hline
\end{tabular}

Sumber : PT Kimia Farma, 2020

Tabel 3. Data Jumlah PPh 23 Bulan September 2019

\begin{tabular}{|l|c|c|c|c|}
\hline Nama User & $\begin{array}{c}\text { Jumlah } \\
\text { Transaksi }\end{array}$ & $\begin{array}{c}\text { Jumlah } \\
\text { PPh 23 }\end{array}$ & Tgl. Setor & $\begin{array}{c}\text { Tgl. Lapor } \\
\text { SPT Masa } \\
\text { PPh 23 }\end{array}$ \\
\hline Jasa Pengepakan & 122.253 .241 & 2.445 .064 & \multirow{2}{*}{$07 / 10 / 2019$} & 0 \\
\cline { 1 - 3 } $\begin{array}{l}\text { Jasa Kebersihan atau Cleaning } \\
\text { Service }\end{array}$ & 28.991 .000 & 579.820 & & \\
\hline Total & 151.244 .241 & $\mathbf{3 . 0 2 4 . 8 8 4}$ & & \\
\hline
\end{tabular}

Sumber : PT Kimia Farma, 2020

\section{Pembahasan}

Berdasarkan hasil penelitian di lapangan, pemotongan pajak pph pasal 23 atas jasa pengepakan dan jasa cleaning service menggunakan tarif $2 \%$. Dasar pemotongan pajak pph pasal 23 yang dilakukan PT Kimia Farma berdasarkan adalah berdasarkan harga transaksi.

Contoh :

a. Transaksi PT Kimia Farma dengan PT Lestari Jaya Raya Sentosa 
pada bulan September 2019 atas jasa pengiriman barang (pengepakan) adalah sebagai berikut: .

Harga transaksi : Rp. 11.581 .873

PPh pasal 23 : $2 \% \times$ Rp. 11.581 .873

: Rp. 231.637.

Maka jumlah pajak pph 23 yg di potong sebesar Rp. 231.637. Dari transaksi diatas maka PT Kimia Farma membayar kepada PT Lestari Jaya Raya Sentosa sebesar Rp. 11.350.236 (setelah dipotong pph pasal 23).

b. Transaksi PT Kimia Farma dengan PT Glori Sukses Makmur pada bulan September 2019 atas jasa kebersihan atau cleaning service adalah sebagai berikut: . Harga transaksi : Rp. 28.991.000

PPh pasal 23 : 2\% x Rp. 28.991 .000

: Rp. 579.820

Maka jumlah pajak pph 23 yg di potong sebesar Rp. 579.820. Dari transaksi diatas maka PT Kimia Farma membayar kepada PT Glori Sukses Makmur sebesar Rp. 28.411.180 (setelah dipotong pph pasal 23)

Dari kedua transaksi diatas, PT Kimia Farma juga memberikan bukti potong pph 23 kepada PT Lestari Jaya Raya Sentosa dan PT Glori Sukses Makmur (dapat dilihat pada tabel 2). Pemotongan pph 23 yg di lakukan PT Kimia Farma sudah sesuai dengan UU ketentuan umum perpajakan.

Sistem penyetoran pph 23 oleh PT Kimia Farma dilakukan menggunakan E-billing. Berdasarkan wawancara dengan salah satu informan, beliau mengatakan bahwa PT Kimia Farma melakukan penyetoran pph asal 23 paling lambat tanggal 10 bulan berikutnya. Begitupun dalam hal pelaporan SPT masa pph pasal 23, PT Kimia Farma termasuk wajib pajak yang patuh (tidak lebih dari tanggal 20 bulan berikutnya). Untuk sistem pelaporan SPT , PT Kimia Farma masih menggunakan cara manual (belum 
menggunakan E-SPT). Pelaporan masih menggunakan sistem manual karena belum ada instruksi dari pusat untuk menerapkan E-Filling dan ESPT.

\section{KESIMPULAN}

\section{Kesimpulan}

Berdasarkan dari penelitian diatas maka penulis berkesimpulan bahwa sistem pemotongan, penyetoran, dan pelaporan pada pph pasal 23 atas jasa pengiriman barang (pengepakan) dan cleaning service pada PT Kimia Farma Trading \& Distibution sudah sesuai dengan UU ketentuan umum perpajakan. PT Kimia Farma dalam melaksanakan kewajiban perpajakannya, termasuk kedalam wajib pajak yang patuh.

\section{Saran}

a. Sebaiknya PT kimia Farma menggunakan E-SPT dalam pelaporannya agar lebih efisien

b. PT Kimia Farma tetap mempertahankan kepatuhannya sebagai wajib pajak agar terhindar dari sanksi administrasi.

\section{DAFTAR PUSTAKA}

Agung, M. (2011). Perpajakan Indonesia Dasar-Dasar Perpajakan dan PPh Wajib Pajak Orang Prib 1

STIE Tri Dharma Nusantaraadi. Jakarta: Lentera IImu Cendekia.

Arfah, M. (2018). Tingkat Kepatuhan Masyarakat Terhadap Pajak Bumi dan Bangunan (PBB) Pada Kantor Desa Pala'lakkang. Makassar.

Dharma, M. (2018). Pelaksanaan, Pemotongan, Penyetoran, dan Pelaporan PPh Pasal 23. Jakarta: GRAHA ILMU.

Hidayat, N., \& Purwana, D. (2017). Perpajakan, Teori dan Praktik. Jakarta: PT RAJAGRAFINDO PERSADA.

Kurniawan, I. (2017). Panduan Praktis Perpajakan. Yogyakarta: CV. ANDI 


\section{OFFSET.}

Mardiasmo, P. (2016). Pepajakan. Yogyakarta: CV ANDI OFFSET.

Mariana, L. (2018). Prosedur Pelaporan SPT Tahunan Badan Lebih Bayar Pada KPP Makassar Barat. Tangible Journal, III(2), 87-102.

Priantara, D. (2016). PERPAJAKAN INDONESIA (Pembahasan Lengkap \& Terkini Disertai CD Praktikum) Edisi 3. Jakarta: Mitra Wacana Media.

Rahayu, S. K. (2017). PERPAJAKAN. Bandung: Rekayasa Sains.

Rahayu, S. K. (2017). Perpajakan Konsep dan Aspek Formal. Bandung: Rekayasa Sains.

Republik Indonesia. (n.d.). "Undang-Undang Republik Indonesia Nomor 28 Tahun 2009 Tentang Pajak Daerah dan Retribusi Daerah".

Resmi, S. (2013). Perpajakan Teori dan Kasus. Jakarta: Salemba Empat.

Resmi, S. (2016). Perpajakan Indonesia. Jakarta: Lentera IImu Cendikia.

Suharsono, A. (2015). Ketentuan Umum Perpajakan. Yogyakarta: GRAHA ILMU.

Tuwo, V. (2016). Pengaruh Sikap dan Kesadaran Wajib Pajak Terhadap Kepatuhan Wajib Pajak Bumi dan Bangunan di Keluarahan Tara-Tara Kota Tomohon. Jurnal EMBA, Vol 4(Nomor 1), 87-97.

Wildyawati, A. (2018). Mekanisme Penagihan dan Pembayaran Pajak Bumi dan Bangunan (PBB) Pada Badan Pendapatan Daerah Kota Makassar. Makassar. 